\title{
Constraints Faced by the Members of Women Dairy Cooperatives in Karnataka, India
}

\author{
L. Niketha ${ }^{1^{*}}$, G. Sankhala ${ }^{1}$, S. Kumar ${ }^{1}$ and K. Prasad ${ }^{2}$ \\ ${ }^{1}$ National Dairy Research Institute, Karnal, India \\ ${ }^{2}$ Indian Institute of Sugar Research, Lucknow, India \\ *Corresponding author
}

\section{A B S T R A C T}

\section{Keywords \\ Constraints, Women, and Women dairy cooperative society \\ Article Info \\ Accepted: \\ 10 April 2018 \\ Available Online: \\ 10 May 2018}

The present study was carried out to analyse the constraints faced by the members of women dairy farmers. Study was conducted in the three districts of Karnataka. A total of six WDC were selected, from each selected WDC forty women dairy farmers were selected randomly for the study. Results reveal that majority of the women perceived that 'illiteracy' was their foremost personal constraint, 'family member do not render help in household work', 'lack of support from family to participate in cultural and community activities', 'multipurpose workload', 'high cost of veterinary medicines', 'lack of interest in political activities', 'lack of technical inability in handling mobile, computers or internet', 'duration of meeting was too long' and 'inadequate space for office of WDC'. In order to have smooth functioning of WDCSs, the impediment needs to be removed.

\section{Introduction}

In this global era, there are lots of economic opportunities and women entrepreneur have emerged as a distinct class. Their contribution towards economy is noteworthy. Women entrepreneurship, directly or indirectly decides the nation's economy and its growth. In India, women with varied social, economic, political, regional and linguistic backgrounds constitute half of the population of nation.

Women's accomplishments are seen solely regarding steady or ward part, for example, a home-maker or mother. Women contribute significantly to patriarchal society mostly in the form of unpaid labour and skills. The value of this effort is under-assessed by the families who take them for granted. Women entrepreneurship in economic development of any nation has been recognized for its significant contribution. Women as entrepreneur is economically more powerful than as a mere worker since proprietorship presents control over resources as well as gives her the freedom to take decision. Along with this achievement they have to perform multiple roles. They make their living through various rural livelihoods. Among the livelihoods, dairying accounts a greater role. The provincial women other than being active partaker at home and homestead activities have been traditionally and predominantly engaged in animal husbandry and dairy 
activities. Women are found to be effectively associated with the upkeep and domestication of dairy cattle. They are the backbone of agrilivestock production system. Indeed dairy and rural women complement each other yet their commitment goes unfiled.

Dairy farming is one of the important enterprises which dominate the economic activities of the women in the provincial territories of India. Increasing demand for milk and milk products in recent years has made dairy enterprise as beneficial endeavor for rustic woman. It plays a more constructive role in promoting rural welfare and reducing poverty by generating employment at farm level. A sustainable and financially viable dairy farming, which will generate income and self-employment through entrepreneurship, is the need of the day (Gamit et al., 2015).

In present days, there are ever increasing number of women looking for monetary opportunity and self-determination through enterprise creation and are very much arranged to grab the opportunities of the multi-polar world. Be that as it may, in the meantime they need to confront various difficulties which are required to be settled by making them and their family mindful and pulling in monetary and moral help in such manner. The woman entrepreneurs have been confronting to several constraints in this sector which hinder their way for development. They are subjected to greater stress due to the demands of home and entrepreneurial activities at times cause conflict and they have to face various constraints. With this background an effort was made to find the constraints faced by rural dairy women entrepreneurs.

\section{Materials and Methods}

The present study was conducted in Shimoga, Davangere and Chitradurga districts of
Karnataka state on a sample of 240 women dairy farmers who were solely the members of women dairy cooperative (WDC) society. A total of six WDC were selected, from each selected WDC forty members' women dairy farmers were selected randomly.

The productivity of different WDCs and dairying are largely affected by varied number of constraints faced by the women. The constraints faced by them were grouped in to major heads related to social, personal, cultural, psychological, economic, political, legal, organisational, infrastructural and technology related constraints.

A three-point frequency continuum was used for the measurement of these constraints. The responses of the individual dairy farmer on each constraint were taken as 'Very serious, 'Serious' and 'Not serious'. For these responses, the scores 3, 2 and 1 were given respectively. The score for each constraint was summed up for all the respondents. The constraint having higher score is considered as more severe. The data were analyzed by using percentage, frequency and Constraint Severity Index.

\section{Constraints of the respondents with respect to women dairy cooperatives}

Any programme or activity no matter how effectively it has been formulated would encounter constraints. It was therefore, assumed that the constraints faced by WDC group members would be of varied nature which would further help to provide alternate suggestions to make WDCs more functional, viable and useful to rural women. If these are tackled effectively, they could be helpful to carry the activity successfully and could indirectly affect the empowerment of women. Table 1 incorporates constraints like social, personal, cultural, economic, psychological, political, legal, technological, organizational 
and infrastructural constraints. On the basis of severity index rank was given to each statement.

\section{Social constraints}

With regard to social constraints, majority of the women perceived that 'family member do not render help in household work' which was ranked first followed by 'dependency of inlaws and small children on members / respondents' (ranked second), 'lack of support from family members to join WDCs' was ranked third while the fourth rank was given to the "women of the family are not free to spend their income independently', 'family members used to pressurize to take loan for household needs / unproductive purposes' (ranked fifth), 'non-cooperative attitude of husband / in-laws' (ranked sixth), seventh rank was given to two statements namely 'dependence on family members for supplying milk' and 'low social acceptability for participation in WDC'. The last constraint amongst social constraint which they felt was 'lack of cooperation among WDC members', which was not a major constraint in the group. The results are in line with Srilatha (2013).

Indian society is prevailed by patriarchal system tilting towards the male so it was obvious that all the household work is to be carried out by women. As the members were in marginalized group, dependency of the family on them for livelihood was an added constraint to them. Social values, beliefs and norms restricting the free intermingling of women with other than the family members might be the reason for the constraint like noncooperative attitude of family members to join WDCs.

\section{Personal constraints}

Most of the members felt 'illiteracy' was their foremost personal constraint (ranked first), 'increased work burden and responsibility' (ranked second) and 'hindrance due to ill health' was their third personal constraint. The results were found to be similar to the results of Srilatha (2013).

The respondents were resource poor farm women, moreover; they were less / not educated much because of less preference to females for education among Indian families at their growing stage were the reasons of personal constraints perceived by the respondents.

\section{Cultural constraints}

'Lack of support from family to participate in cultural and community activities' was ranked first among cultural constraints faced by the respondents, while 'women were often ignored or hesitated to take decisions for the betterment of society and family itself' (ranked second) and 'interference of family members to attend visits/trips organized by WDC or any pilgrim / religious places' was ranked as a third constraint. Cultural constraints were encountered by the women because of deep rooted cultural values, beliefs, norms not permitting the free movement of women in our society.

\section{Psychological constraints}

Regarding psychological constraints, 'multipurpose workload' (ranked first), was their major obstacle followed by 'lack of motivation among members' (ranked second), 'poor involvement of members in decision making activities in WDCs' was ranked third, 'lack of self-confidence' (ranked fourth) and 'excessive stress and tension of dual responsibility’ (ranked fifth).

Lack of supportive environment among the resource poor Indian farm families at household as well as WDC level might be 
possible reasons of the psychological constraints perceived by them.

\section{Economic constraints}

Almost majority of the members felt 'high cost of veterinary medicines' (ranked first) was their main constraint, 'male members dominance on family incomes and expenditures' was ranked as a second obstacle while they felt 'high artificial insemination (AI) charges' were high was third ranked constraint, 'lack of affordability to purchase feed additives and concentrates' was ranked fourth, 'low income' (ranked fifth), 'high charges for emergency services' (ranked sixth), 'inequality in issuing loans' (ranked seventh), 'information about transactions and financial activities in WDC' are not shared with members (ranked eighth) and 81.25 percent of the respondents disagreed there was a 'improper utilization of WDC funds' which was given the last rank (ranked ninth), which indicates the transparent transactions in the group and members maintain the confidence with each other.

Poor economic condition of the members resulted in lower surplus income leading to the less affordability to incur the expenditure on inputs and lack of control over economic resources by women might be the possible reasons of the economic constraints.

\section{Political constraints}

In order of severity 'lack of interest in political activities' was found to be major constraint with first rank, 'members felt lack of effort for creating political awareness' among women which was ranked second, 'political affiliation vitiate in the working environment of WDC societies' (ranked third) and 'lack of effective leadership in WDC' was the (ranked fourth) least ranked statement by the members. Need hierarchy principle might be the possible reasons of the political constraints felt by the dairy women. Further, the ill well prevailing among the masses against the Indian political system might be another reason for lack of interest in political activities.

\section{Legal constraints}

Among the legal constraints, 'displeasure and noncooperation attitude of families to a women member to consult or approach the law enforcement bodies' was the first constraint while, 'lack of knowledge about the women rights for their empowerment' was given the second rank and 'lack of systematic effort for addressing social issues' was ranked as a third constraint by the members.

The Indian social system and customs does not permit the Indian families to stand against the family members. This might be the possible reason for above constraints encountered by the dairy women members.

\section{Constraints related to technology}

'Lack of technical inability in handling mobile, computers or internet' was the first and foremost constraint amidst of the other technological constraints. 'Lack of technical training for green fodder' was ranked as second constraint, 'inadequate availability of fodder seeds' (ranked third), 'lack of high yielding varieties (HYV) in fodder crops' (ranked fourth), 'lack of awareness about advantages and facilities provided by government and milk unions for rearing animals' was ranked fifth and 'poor skilled staff at AI centres' was given the last rank (ranked sixth). The findings are in line with Srilatha (2013). Since the majority of the members were poor they do not possess modern electronic gadgets so they lack proficiency in handling them with the added reason the majority members were not much literate. 
Table.1 Distribution of the respondents according to constraints faced by members of WDCs

\begin{tabular}{|c|c|c|c|c|c|c|}
\hline & & & & & & $\mathrm{n}=240$ \\
\hline Sl. & Constraints & Exto & nt of seriou & sness & Constraint & Rank \\
\hline No. & & $\begin{array}{l}\text { More } \\
\text { serious }\end{array}$ & Serious & $\begin{array}{l}\text { Not } \\
\text { serious }\end{array}$ & $\begin{array}{c}\text { Severity } \\
\text { Index }\end{array}$ & \\
\hline & & $\begin{array}{l}\mathbf{f} \\
(\%)\end{array}$ & $\begin{array}{c}\mathbf{f} \\
(\%)\end{array}$ & $\begin{array}{l}\mathbf{f} \\
(\%)\end{array}$ & & \\
\hline Soci & Constraints & & & & & \\
\hline 1 & $\begin{array}{l}\text { Lack of cooperation among WDC } \\
\text { members }\end{array}$ & $\begin{array}{l}40 \\
(16.67)\end{array}$ & $\begin{array}{l}61 \\
(25.40)\end{array}$ & $\begin{array}{l}139 \\
(57.93)\end{array}$ & 15.00 & VIII \\
\hline 2 & $\begin{array}{l}\text { Family members used to pressurise } \\
\text { to take loan for household needs / } \\
\text { unproductive purposes }\end{array}$ & $\begin{array}{l}15 \\
(6.25)\end{array}$ & $\begin{array}{l}42 \\
(17.50)\end{array}$ & $\begin{array}{l}183 \\
(76.25)\end{array}$ & 29.38 & $\mathbf{V}$ \\
\hline 3 & $\begin{array}{l}\text { Lack of support from family } \\
\text { members to join WDC activities }\end{array}$ & $\begin{array}{l}61 \\
(25.42)\end{array}$ & $\begin{array}{l}79 \\
(32.91)\end{array}$ & $\begin{array}{l}100 \\
(41.67)\end{array}$ & 41.86 & III \\
\hline 4 & $\begin{array}{l}\text { Family member do not render help } \\
\text { in house hold work }\end{array}$ & $\begin{array}{l}93 \\
(38.75)\end{array}$ & $\begin{array}{l}86 \\
(35.83)\end{array}$ & $\begin{array}{l}61 \\
(25.42)\end{array}$ & 56.66 & I \\
\hline 5 & $\begin{array}{l}\text { Non-cooperative attitude of } \\
\text { husband/in-laws }\end{array}$ & $\begin{array}{l}29 \\
(12.08)\end{array}$ & $\begin{array}{l}70 \\
(29.20)\end{array}$ & $\begin{array}{l}141 \\
(58.72)\end{array}$ & 26.66 & VI \\
\hline 6 & $\begin{array}{l}\text { Dependence on family members for } \\
\text { supplying milk }\end{array}$ & $\begin{array}{l}22 \\
(9.17)\end{array}$ & $\begin{array}{l}43 \\
(17.90)\end{array}$ & $\begin{array}{l}175 \\
(72.93)\end{array}$ & 18.13 & VII \\
\hline 7 & $\begin{array}{l}\text { Low social acceptability for } \\
\text { participation in WDC }\end{array}$ & $\begin{array}{l}22 \\
(9.17)\end{array}$ & $\begin{array}{l}43 \\
(17.90)\end{array}$ & $\begin{array}{l}175 \\
(72.93)\end{array}$ & 18.13 & VII \\
\hline 8 & $\begin{array}{l}\text { The women of the family are not } \\
\text { free to spend their income } \\
\text { independently }\end{array}$ & $\begin{array}{l}62 \\
(25.83)\end{array}$ & $\begin{array}{l}65 \\
(27.10)\end{array}$ & $\begin{array}{l}113 \\
(47.08)\end{array}$ & 39.38 & IV \\
\hline 9 & $\begin{array}{l}\text { Dependency of in-laws \& small } \\
\text { children on members / respondents }\end{array}$ & $\begin{array}{l}76 \\
(31.67)\end{array}$ & $\begin{array}{l}61 \\
(25.40)\end{array}$ & $\begin{array}{l}103 \\
(42.92)\end{array}$ & 44.38 & II \\
\hline Per: & nal Constraints & & & & & \\
\hline 1 & $\begin{array}{l}\text { Increased work burden and } \\
\text { responsibility }\end{array}$ & $\begin{array}{l}79 \\
(32.92)\end{array}$ & $\begin{array}{l}73 \\
(30.42)\end{array}$ & $\begin{array}{l}88 \\
(36.66)\end{array}$ & 48.13 & II \\
\hline 2 & Hindrance due to ill health & $\begin{array}{l}18 \\
(7.50)\end{array}$ & $\begin{array}{l}70 \\
(29.17)\end{array}$ & $\begin{array}{l}152 \\
(63.33)\end{array}$ & 22.08 & III \\
\hline 3 & Illiteracy & $\begin{array}{l}106 \\
(44.17)\end{array}$ & $\begin{array}{l}80 \\
(33.33)\end{array}$ & $\begin{array}{l}54 \\
(22.50)\end{array}$ & 60.83 & I \\
\hline Cul & Iral Constraints & & & & & \\
\hline 1 & $\begin{array}{l}\text { Women are often ignored or hesitate } \\
\text { to take decisions for the betterment } \\
\text { of society and family itself }\end{array}$ & $\begin{array}{l}73 \\
(30.42)\end{array}$ & $\begin{array}{l}53 \\
(22.08)\end{array}$ & $\begin{array}{l}114 \\
(47.50)\end{array}$ & 41.46 & II \\
\hline 2 & $\begin{array}{l}\text { Interference of family members to } \\
\text { attend visits/trips organised by WDC } \\
\text { or any pilgrim/religious places }\end{array}$ & $\begin{array}{l}76 \\
(31.67)\end{array}$ & $\begin{array}{l}44 \\
(18.33)\end{array}$ & $\begin{array}{l}120 \\
(50.00)\end{array}$ & 40.83 & III \\
\hline 3 & $\begin{array}{l}\text { Lack of support from family to } \\
\text { participate in cultural and } \\
\text { community activities }\end{array}$ & $\begin{array}{l}86 \\
(35.83)\end{array}$ & $\begin{array}{l}67 \\
(27.92)\end{array}$ & $\begin{array}{l}87 \\
(36.25)\end{array}$ & 49.79 & $\mathbf{I}$ \\
\hline
\end{tabular}




\begin{tabular}{|c|c|c|c|c|c|c|}
\hline \multicolumn{7}{|c|}{ Psychological Constraints } \\
\hline 1 & Multipurpose work load & $\begin{array}{l}72 \\
(30.00)\end{array}$ & $\begin{array}{l}85 \\
(35.42)\end{array}$ & $\begin{array}{l}83 \\
(34.58)\end{array}$ & 47.71 & I \\
\hline 2 & $\begin{array}{l}\text { Poor involvement of members in } \\
\text { decision-making activities in WDC }\end{array}$ & $\begin{array}{l}18 \\
(7.50)\end{array}$ & $\begin{array}{l}54 \\
(22.50)\end{array}$ & $\begin{array}{l}168 \\
(70.00)\end{array}$ & 18.75 & III \\
\hline 3 & $\begin{array}{l}\text { Lack of motivations among } \\
\text { members }\end{array}$ & $\begin{array}{l}51 \\
(21.25)\end{array}$ & $\begin{array}{l}41 \\
(17.08)\end{array}$ & $\begin{array}{l}148 \\
(61.67)\end{array}$ & 29.79 & II \\
\hline 4 & $\begin{array}{l}\text { Excessive stress and tension of dual } \\
\text { responsibility }\end{array}$ & $\begin{array}{l}22 \\
(9.17)\end{array}$ & $\begin{array}{l}41 \\
(17.08)\end{array}$ & $\begin{array}{l}177 \\
(73.75)\end{array}$ & 17.71 & $\mathbf{V}$ \\
\hline 5 & Lack of self-confidence & $\begin{array}{l}25 \\
(10.42)\end{array}$ & $\begin{array}{l}38 \\
(15.83)\end{array}$ & $\begin{array}{l}177 \\
(73.75)\end{array}$ & 18.33 & IV \\
\hline \multicolumn{7}{|c|}{ Economic Constraints } \\
\hline 1 & Improper utilization of WDC funds & $\begin{array}{l}18 \\
(7.50)\end{array}$ & $\begin{array}{l}27 \\
(11.25)\end{array}$ & $\begin{array}{l}195 \\
(81.25)\end{array}$ & 13.33 & IX \\
\hline 2 & Inequality in issuing loans & $\begin{array}{l}36 \\
(15.00)\end{array}$ & $\begin{array}{l}43 \\
(17.92)\end{array}$ & $\begin{array}{l}161 \\
(67.08)\end{array}$ & 23.96 & VII \\
\hline 3 & $\begin{array}{l}\text { Information about transactions and } \\
\text { financial activities in WDC are not } \\
\text { shared with members }\end{array}$ & $\begin{array}{l}23 \\
(9.59)\end{array}$ & $\begin{array}{l}43 \\
(17.91)\end{array}$ & $\begin{array}{l}174 \\
(72.50)\end{array}$ & 18.54 & VIII \\
\hline 4 & Low Income & $\begin{array}{l}38 \\
(15.83)\end{array}$ & $\begin{array}{l}62 \\
(25.84)\end{array}$ & $\begin{array}{l}140 \\
(58.33)\end{array}$ & 28.75 & V \\
\hline 5 & AI charges are high & $\begin{array}{l}67 \\
(27.92)\end{array}$ & $\begin{array}{l}61 \\
(25.42)\end{array}$ & $\begin{array}{l}112 \\
(46.66)\end{array}$ & 40.00 & III \\
\hline 6 & High charges for emergency services & $\begin{array}{l}39 \\
(16.25)\end{array}$ & $\begin{array}{l}54 \\
(22.50)\end{array}$ & $\begin{array}{l}147 \\
(61.25)\end{array}$ & 27.50 & VI \\
\hline 7 & $\begin{array}{l}\text { Lack of affordability to purchase } \\
\text { feed additives \& concentrates }\end{array}$ & $\begin{array}{l}70 \\
(29.17)\end{array}$ & $\begin{array}{l}52 \\
(21.67)\end{array}$ & $\begin{array}{l}118 \\
(49.16)\end{array}$ & 40.00 & IV \\
\hline 8 & High cost of veterinary medicines & $\begin{array}{l}118 \\
(49.17)\end{array}$ & $\begin{array}{l}71 \\
(29.58)\end{array}$ & $\begin{array}{l}51 \\
(21.25)\end{array}$ & 63.96 & I \\
\hline 9 & $\begin{array}{l}\text { Male member dominancy on family } \\
\text { income \& expenditures }\end{array}$ & $\begin{array}{l}67 \\
(27.92)\end{array}$ & $\begin{array}{l}100 \\
(41.67)\end{array}$ & $\begin{array}{l}73 \\
(30.41)\end{array}$ & 48.75 & II \\
\hline \multicolumn{7}{|c|}{ Political Constraints } \\
\hline 1 & $\begin{array}{l}\text { Lack of interest in political } \\
\text { activities }\end{array}$ & $\begin{array}{l}108 \\
(45.00)\end{array}$ & $\begin{array}{l}81 \\
(33.75)\end{array}$ & $\begin{array}{l}51 \\
(21.25)\end{array}$ & 61.88 & I \\
\hline 2 & $\begin{array}{l}\text { Lack of effort for creating political } \\
\text { awareness among women }\end{array}$ & $\begin{array}{l}93 \\
(38.75)\end{array}$ & $\begin{array}{l}78 \\
(32.50)\end{array}$ & $\begin{array}{l}69 \\
(28.75)\end{array}$ & 55.00 & II \\
\hline 3 & $\begin{array}{l}\text { Lack of effective leadership in } \\
\text { WDCs }\end{array}$ & $\begin{array}{l}46 \\
(19.17)\end{array}$ & $\begin{array}{l}58 \\
(24.17)\end{array}$ & $\begin{array}{l}136 \\
(56.66)\end{array}$ & 31.25 & IV \\
\hline 4 & $\begin{array}{l}\text { Political affiliation vitiate in the } \\
\text { working environment of WDCs } \\
\text { societies }\end{array}$ & $\begin{array}{l}78 \\
(32.50)\end{array}$ & $\begin{array}{l}49 \\
(20.42)\end{array}$ & $\begin{array}{l}113 \\
(47.08)\end{array}$ & 42.71 & III \\
\hline \multicolumn{7}{|c|}{ Legal Constraints } \\
\hline 1 & $\begin{array}{l}\text { Lack of systematic effort for } \\
\text { addressing social issues }\end{array}$ & $\begin{array}{l}57 \\
(23.75)\end{array}$ & $\begin{array}{l}68 \\
(28.33)\end{array}$ & $\begin{array}{l}115 \\
(47.92)\end{array}$ & 37.92 & III \\
\hline
\end{tabular}




\begin{tabular}{|c|c|c|c|c|c|c|}
\hline 2 & $\begin{array}{l}\text { Lack of knowledge about the } \\
\text { women rights for their } \\
\text { empowerment }\end{array}$ & $\begin{array}{l}58 \\
(24.17)\end{array}$ & $\begin{array}{l}74 \\
(30.83)\end{array}$ & $\begin{array}{l}108 \\
(45.00)\end{array}$ & 39.58 & II \\
\hline 3 & $\begin{array}{l}\text { Displeasure and non-cooperative } \\
\text { attitude of families to a women } \\
\text { member to consult or approach the } \\
\text { law enforcement bodies }\end{array}$ & $\begin{array}{l}79 \\
(32.92)\end{array}$ & $\begin{array}{l}67 \\
(27.92)\end{array}$ & $\begin{array}{l}94 \\
(39.16)\end{array}$ & 46.88 & I \\
\hline \multicolumn{7}{|c|}{ Constraints related to Technology } \\
\hline 1 & $\begin{array}{l}\text { Lack of awareness about } \\
\text { advantages and facilities provided } \\
\text { by Govt. and milk unions for } \\
\text { rearing animals }\end{array}$ & $\begin{array}{l}51 \\
(21.25)\end{array}$ & $\begin{array}{l}71 \\
(29.58)\end{array}$ & $\begin{array}{l}118 \\
(49.17)\end{array}$ & 36.04 & V \\
\hline 2 & $\begin{array}{l}\text { Lack of technical training for } \\
\text { growing green fodder }\end{array}$ & $\begin{array}{l}85 \\
(35.42)\end{array}$ & $\begin{array}{l}73 \\
(30.42)\end{array}$ & $\begin{array}{l}82 \\
(34.16)\end{array}$ & 50.63 & II \\
\hline 3 & $\begin{array}{l}\text { Inadequate availability of fodder } \\
\text { seeds }\end{array}$ & $\begin{array}{l}52 \\
(21.67)\end{array}$ & $\begin{array}{l}77 \\
(32.08)\end{array}$ & $\begin{array}{l}111 \\
(46.25)\end{array}$ & 37.71 & III \\
\hline 4 & $\begin{array}{l}\text { Technical inability in handling ICT } \\
\text { tools }\end{array}$ & $\begin{array}{l}152 \\
(63.33)\end{array}$ & $\begin{array}{l}47 \\
(19.58)\end{array}$ & $\begin{array}{l}41 \\
(17.09)\end{array}$ & 73.13 & I \\
\hline 5 & $\begin{array}{l}\text { Lack of high yielding varieties } \\
\text { (HYV) in fodder crops }\end{array}$ & $\begin{array}{l}55 \\
(22.92)\end{array}$ & $\begin{array}{l}66 \\
(27.50)\end{array}$ & $\begin{array}{l}119 \\
(49.58)\end{array}$ & 36.67 & IV \\
\hline 6 & Poor skilled staff at AI centers & $\begin{array}{l}24 \\
(10.00)\end{array}$ & $\begin{array}{l}41 \\
(17.08)\end{array}$ & $\begin{array}{l}175 \\
(72.92)\end{array}$ & 18.54 & VI \\
\hline \multicolumn{7}{|c|}{ Organisational Constraints } \\
\hline 1 & $\begin{array}{l}\text { Inappropriate distribution of } \\
\text { benefits }\end{array}$ & $\begin{array}{l}34 \\
(14.17)\end{array}$ & $\begin{array}{l}38 \\
(15.83)\end{array}$ & $\begin{array}{l}168 \\
(70.00)\end{array}$ & 22.00 & III \\
\hline 2 & Proper accounts are not maintained & $\begin{array}{l}14 \\
(05.83)\end{array}$ & $\begin{array}{l}42 \\
(17.50)\end{array}$ & $\begin{array}{l}184 \\
(76.67)\end{array}$ & 14.58 & V \\
\hline 3 & $\begin{array}{l}\text { Inadequate profit from WDC } \\
\text { activities }\end{array}$ & $\begin{array}{l}8 \\
(3.33)\end{array}$ & $\begin{array}{l}64 \\
(26.67)\end{array}$ & $\begin{array}{l}168 \\
(70.00)\end{array}$ & 16.67 & IV \\
\hline 4 & Duration of meeting is too long & $\begin{array}{l}130 \\
(54.17)\end{array}$ & $\begin{array}{l}75 \\
(31.25)\end{array}$ & $\begin{array}{l}35 \\
(14.58)\end{array}$ & 69.79 & I \\
\hline 5 & $\begin{array}{l}\text { Lack of coordination among } \\
\text { members with the management }\end{array}$ & $\begin{array}{l}38 \\
(15.83)\end{array}$ & $\begin{array}{l}76 \\
(31.67)\end{array}$ & $\begin{array}{l}126 \\
(52.50)\end{array}$ & 31.67 & II \\
\hline \multicolumn{7}{|c|}{ Infrastructural Constraints } \\
\hline 1 & $\begin{array}{l}\text { Inadequate space for office of } \\
\text { WDC }\end{array}$ & $\begin{array}{l}130 \\
(54.17)\end{array}$ & $\begin{array}{l}58 \\
(24.17)\end{array}$ & $\begin{array}{l}52 \\
(21.66)\end{array}$ & 66.25 & I \\
\hline 2 & $\begin{array}{l}\begin{array}{l}\text { Distant location of dairy } \\
\text { cooperative office }\end{array}\end{array}$ & $\begin{array}{l}46 \\
(19.17)\end{array}$ & $\begin{array}{l}66 \\
(27.50)\end{array}$ & $\begin{array}{l}128 \\
(53.33)\end{array}$ & 32.92 & $\mathbf{V}$ \\
\hline 3 & $\begin{array}{l}\text { Lack of physical facilities at } \\
\text { meeting place }\end{array}$ & $\begin{array}{l}117 \\
(48.75)\end{array}$ & $\begin{array}{l}76 \\
(31.67)\end{array}$ & $\begin{array}{l}47 \\
(19.58)\end{array}$ & 64.58 & II \\
\hline 4 & $\begin{array}{l}\text { AI centers are located at distant } \\
\text { places }\end{array}$ & $\begin{array}{l}88 \\
(36.67)\end{array}$ & $\begin{array}{l}95 \\
(39.58)\end{array}$ & $\begin{array}{l}57 \\
(23.75)\end{array}$ & 56.46 & III \\
\hline 5 & $\begin{array}{l}\text { Inadequate \& interrupted power } \\
\text { supply in rural areas }\end{array}$ & $\begin{array}{l}65 \\
(27.08)\end{array}$ & $\begin{array}{l}82 \\
(34.17)\end{array}$ & $\begin{array}{l}93 \\
(38.75)\end{array}$ & 44.17 & IV \\
\hline
\end{tabular}

(Figures in parentheses indicate percentages) 


\section{Organisational Constraints}

Among organisational constraints, majority of the members felt 'duration of meeting was too long' (ranked first), 'lack of coordination among members with the management' was ranked second, 'inappropriate distribution of benefits' as third, 'inadequate profit from WDC activities' (ranked fourth) and 'proper accounts were not maintained' was assigned the last rank (ranked fifth) by the respondents. Women members were over-burdened with multi-faceted work load because of that they could not spare much time for meeting.

\section{Infrastructural constraints}

Members felt 'inadequate space for office of WDC' as the first constraint among infrastructural constraints. While 'lack of physical facilities at meeting place' was ranked second followed by 'artificial insemination (AI) centers at distant places' as third, the fourth constraint was 'inadequate and interrupted power supply in rural areas' and the last constraint (ranked fifth) was 'dairy cooperative society was far away from home'. The findings are in line with Kaur et al., (2007) and Meena et al., (2013). The WDC offices were congested to carry out all the activities in such a small room and it was also lacking with many amenities required.

It can be concluded that in a patriarchal society, women were over-loaded with multiwork responsibilities. In addition women have to face social barriers and family problems. Majority of the women members were daunted by families to take part in cultural and community activities. As respondents were mainly landless, small and marginal farmers they felt cost of veterinary medicines were high. The results indicated that most of them used the money in activities related to agriculture mainly rearing and fattening of livestock. In order to fatten, fodder is an important input. Scarcity of fodder especially in dry seasons was a challenge and during drought the price of fodder to go up thereby many landless and marginal farmers were snagged due to hike of prices.

Though direct payment was made in the hands of women members, there was still dominance of male members on it where few respondents expressed that some women members do not enjoy economic freedom to the greater extent.

Rural women continue to face a number of constraints on their ability to participate in formal and informal decision-making processes. The predominant responsibility for household tasks continues to be assigned to women and limits their time and opportunities to be actively involved in educational, social and political activities. Discriminatory and stereotypical attitudes, lack of education, security concerns and freedom of movement may also limit opportunities for women to participate. Illiteracy trammeled the members which hindered them from using modern tools and technologies like handling mobile, computers or internet and limited their participation in many social arenas activities. Time and labour constraints also hinder women as do mobility or restrictions due to so-called "cultural reservations". Political intervention in the WDCs was also found to hamper the empowerment process.

Most of the members felt illiteracy was their foremost personal constraint, lack of support from family to participate in cultural \& community activities was ranked first among cultural constraints, under psychological constraints; multipurpose workload was their major obstacle, majority of the members felt high cost of veterinary medicines was the main economic constraint, lack of interest in political activities was among political constraint, displeasure and non-cooperative 
attitude of families to a women member to consult or approach the law enforcement bodies was the major legal constraint, lack of technical inability in handling. It might be concluded that the area of study was lacking infrastructural facilities, members were over loaded with multi-faceted responsibilities, high cost of veterinary medicines, etc., therefore, if these facilities could be provided to WDC members then their dairy farming might become more productive as well as profitable.

Unless the seriousness of these constraints are minimized through initiating appropriate actions by the administrators as well as other stakeholders involved, the extent of dairy development will not be effective and smooth. Policies and programmes to be devised and implemented to minimize the intensity of constraints.

\section{References}

Gangasagare P T and Karanjkar L M (2009) Constraints in adapting animal husbandry practices by the dairy farmers in the Marathwada region of Maharashtra. Veterinary World. 2(9): 347-349
Jayalekshmi G (1996): Entrepreneurial behaviour of rural women in Trivandrum District, M.Sc., (Ag.) thesis TNAU, Coimbatore

Mariammal R, Seethalakshmi $M$ and Narmatha N (2017) Constraints Faced by the Women Dairy Farmers and their Suggestions to Improve the Dairy Enterprise. Academy of agriculture journal. 2(7): 18-21.

Naila K (2005) Gender equality and women's empowerment: a critical analysis of the third Millennium Development Goal. Gender and Development. 13 (1): pp. 13-24.

Pandit J C and N C Basak (2013) Constraints faced by the farmers in commercial cultivation of vegetables. Journal of Bangladesh Agril. Univ. 11(2): 193198.

Patil A P, Gawande S H, Nande M P and M R Gobade (2009) Constraints Faced by the Dairy Farmers in Nagpur District while Adopting Animal Management Practices. Veterinary World. 2(3): 111112

Savitha C M, Siddaramaiah B S and Shankara M H (2014) Constraints faced by rural and urban women entrepreneurs. International Journal of Farm Sciences. 5(2): 231-235

\section{How to cite this article:}

Niketha, L., G. Sankhala, S. Kumar and Prasad, K. 2018. Constraints Faced by the Members of Women Dairy Cooperatives in Karnataka, India. Int.J.Curr.Microbiol.App.Sci. 7(05): 977-985. doi: https://doi.org/10.20546/ijcmas.2018.705.121 